\title{
Conflict Management, Honor, and Organizational Change ${ }^{1}$
}

\author{
Calvin Morrill \\ University of Arizona
}

How do top managers of a large American corporation manage conflict among themselves? This article investigates intracorporate executive conflict management in a Fortune 500 manufacturer via ethnographic methods. It focuses on the links between executive conflict management and widespread innovations in (1) top managerial formal structure and (2) hostile takeovers and their symbolic imagery. More specifically, the article focuses on how these innovations disrupted the traditional social structure and "rules of the game" among top managers. The resulting new "culture of honor" suggests several implications for the study of managerial uncertainty, inertia, accountability, and control in contemporary American corporations.

The grey-suited managers directing large corporations seem unlikely practitioners of elaborate honor ceremonies. A top manager from Kanter's (1977, p. 48) study of a large corporation, for example, portrayed his executive offices as a "brain center, but there is no activity. It's like an old folks' home. You can see the cobwebs growing. A secretary every quarter of a mile. It's very sterile." Moore's (1962, p. 127) observations on executive conflict echo these sentiments: "Let us understand, this is a discussion among gentlemen, not a barroom brawl. The decor and the demeanor require restraint. This is civilized combat, not the law of the jungle." The images evoked by Kanter, Moore, and studies

\footnotetext{
${ }^{1}$ A junior fellowship at the Center for Criminal Justice, Harvard Law School, and the Program in Law and Social Sciences of the National Science Foundation (grant SES-8508349) provided financial assistance for this research. Donald Black, Donald Cressey, Keith Morrill, Ruth Morrill, Laura Nader, Alesandro Pizzorno, Harrison White, and personnel at "Playco" provided invaluable comments and support during the execution of the fieldwork. I thank William Bailey, M. P. Baumgartner, Donald Black, Michael Burgoon, Mark Cooney, Steve Cornell, Donald Cressey, Mustafa Emirbayer, Paul Hirsch, Allan Horwitz, John Johnson, Rosabeth Moss Kanter, Michele Lamont, Eric Leifer, Michael Musheno, Dirk Scheerhorn, David Snow, James Tucker, Harrison White, members of the Social Organization seminar led by Walter Powell and the Qualitative Methods graduate seminar, both at the University of Arizona, and three anonymous $A J S$ reviewers for helpful comments on earlier drafts of the paper. I also thank Barbara McIntosh for help in preparing the manuscript.
}

(C) 1991 by The University of Chicago. All rights reserved.

0002-9602/92/9703-0001\$01.50 
by Dalton (1959) and Macaulay (1963) suggest a buttoned-down culture in American corporate suites.

Such an expectation might accurately characterize corporate executive suites prior to the 1980 s. Since that time two significant developments have disrupted the traditional social structures and "rules of the game" among top management: (1) widespread restructuring of corporate management, particularly experimentation with "matrix" management; and (2) the diffusion of hostile takeovers and their symbolic imagery. In this article I explore the impacts of these developments on top managers through the symbolic reframing of their conflict management in a large corporation. ${ }^{2}$

At a theoretical level, the article illustrates the utility of cross-cultural theories of conflict management for understanding behavior in organizational contexts. The study also suggests the concurrent importance of both social structural and symbolic factors enacted either purposively or conjuncturally in explaining organizational change. In this sense, "structure" and "symbolic systems" interact with each other and exist as overlapping social phenomena: social structure cannot exist without symbolic systems, which individuals use to make sense of, maintain, and change social structure, while symbolic systems cannot exist for long without "plausibility structures," which root symbols in behavioral patterns (Berger and Luckman 1966). Central in this process is what Thompson $(1967$, p. 148) views as a crucial paradox in complex organizations: the desire for flexibility and certainty to occur simultaneously in administration. In the corporation under study, ideas and practices related to matrix management appeared as a way to achieve administrative flexibility by loosening authority relations. The adoption of the matrix, however, led to great internal uncertainty within a wider environment of uncertainty caused by the advent of hostile takeovers. At the same time, the matrix created the structural conditions conducive to highly ritualized conflict management framed in a code of honor inspired by imagery associated with the rise of hostile takeovers and local imagery associated with the corporation's products. It is this code of honor that allows executives to make sense of the turbulent American business world born of the 1980s. As I will argue at the conclusion of the paper, this ritualized conflict management may also increase organizational inertia at the executive levels, control by top managers over executive subordinates, and executive accountability, but such conflict management raises doubts about the efficacy of economic theories of the firm. I begin with a look at executive social organization and conflict management prior to the

${ }^{2}$ Conflict management refers to any social process by which people or groups handle grievances about each other's behaviors (see generally, Black 1984, 1990; Nader and Todd 1978). 
1980s at Playco, my pseudonym for the organization I studied. Data collection and analysis methods are described in Appendix A. Appendix B contains a glossary of terms used by executives. ${ }^{3}$

\section{EXECUTIVE SOCIAL ORGANIZATION AND CONFLICT MANAGEMENT PATTERNS, CIRCA 1975}

In the mid-1970s, Playco manufactured several lines of toys for small children. Its executive core consisted of 21 top managers organized into several departments. There were only three ranks: vice president, senior vice president (who headed departments), and the president/chief executive of the firm. A long-time executive described the executive levels at Playco as "staid" and "laid back."

The substance of conflict during this period focused around four broad issues: diversification of Playco's product lines, production scheduling, the gradual removal of the founders of the firm from central sources of power (one chaired the board of directors, while the other occupied the presidency), and what several executives referred to as "personality conflicts between individuals." The following accounts by two executives who have worked with Playco since the 1960s summarizes the tone of executive conflict management at the firm in the mid-1970s:

Account 1. Let me give you a couple of examples. We used to have conflicts between departments: engineering and design. In those days, the president always settled them, when the two department VPs [vice presidents] couldn't get a grip on it. But it was all done very quietly, behind closed doors. You wouldn't dare shout at one of your colleagues. It was a different world then. There was also a lot more discipline within the departments. I remember being a young VP and working for this complete horse's patoot of a SVP [senior vice president]. I would never even think about challenging him the way VPs challenge their SVPs in the firm today. I had to change in the eighties. I had to get with the game myself; get more

${ }^{3}$ Few ethnographies exist that focus on corporate executives. Moore's (1962), Macaulay's (1963), and Kanter's (1977) studies do not exclusively focus on executives, but provide broad support for the staid characterization of executive suites prior to the 1980s. Morrill's (1989) ethnography of executive conflict in a Fortune 100 bank in the 1980s also provides a point of comparison (noted in the text below) between corporations involved and not involved with hostile takeovers and matrix management. Studies of executives by business scholars are less useful for my purposes because of their focus on normative concerns relevant to managerial practice. The mostcited studies in the business literature are Carlson's (1951) study of work activities by Swedish executives in which subjects keep daily dairies; Mintzberg's (1973) "structured observation" of the individual activities of six top managers in different organizations; and Kotter's (1983) observational and self-report study on the "secrets" of 15 "successful" executives drawn from manufacturing and nonmanufacturing organizations. Martynko and Gardner (1985) provide a useful review of these works and those related to observational studies of middle and lower managers. 
aggressive, take people on in public. It took a while. I sometimes think it hurt me; not getting with the game until a few years ago.

Account 2. The only public conflicts I remember happened when the founders bowed out of the firm in the early seventies. There were some donnybrooks over that. We [the executive and two other senior executives] were hired to help them run this itsy bitsy firm that had grown into a multinational corporation over [a] 30-year period. We wound up running the firm. Hey, I sat around here grumbling about [the founders] for years before anything came out in the open. The same thing with personal issues I had with colleagues. All of the stuff you see on a daily basis around here now just didn't happen back then. Divisional managers [senior vice presidents] kept their shops clean; people kept to themselves. Sure, there were problems, conflicts between top execs. But it got settled quietly.

Other executives and consultants working in or with Playco prior to the late 1970s echo these sentiments. Conflict management took particular forms according to its downward or upward direction as in other unitary managerial hierarchies (Dalton 1959; Morrill 1989). Conflict management among Playco executives also exhibited certain ceremonies (Trice, Belasco, and Alutto 1969) marking its occurrence and conclusion. A consistent ritual was that of removing a conflict from the public view and handling it as quietly as possible "behind closed doors" as the executive noted in account 1 . When approaching a superior in a conflictive situation, subordinates tended to make special appointments to see their superiors alone and tended to rehearse the presentation of their grievances. More often than not, such presentations were "cut off" by superiors who settled the matter unilaterally after briefly listening to their subordinate's opening remarks. The superior would then return his or her subordinate back to their regular duties to "work out the details of the solution." Superiors with complaints against their subordinates would usually call those subordinates into their office for a quick meeting to "clear up problems." Although some executives reported "rehearsing" their presentations to subordinates, most argued that such actions tended to occur without much thought about how they would specifically present their grievance. Accounts of peer conflicts contain consistent references to the private conflict management as well. The next two sections of this article demonstrate that the unity of command and the patterns of conflict management associated with it changed dramatically by the mid-1980s.

\section{EXECUTIVE SOCIAL ORGANIZATION: $1984-87^{4}$}

\section{The Corporation}

Playco manufactures computers, electronic learning aids, and electronic toys and games for children as well as owning publishing houses, movie

\footnotetext{
${ }^{4}$ Material from the 1980 s is presented in the ethnographic "present."
} 
studios, computer manufacturers, small chemical companies, and numerous other subsidiaries. Forty-three executives (holding titles of vice president or above) and some 3,000 other employees work at its headquarters. The company is publicly owned.

The majority of Playco top managers are white males between the ages of 35 and 65; they hold college and graduate degrees and are married with children. Women make up nearly one-fifth of its executives (cf. Kanter 1977, pp. 29-68). About one-third of the executives in the company have 15 years of service or more, one-third have 10-15 years of service, and the rest have worked for the company less than 10 years. Executives based at the company's headquarters are rarely transferred to other Playco facilities. Executives at headquarters, however, do transfer duties.

Executives estimate that Playco replaces between $40 \%$ and $60 \%$ of its products every year (slightly lower than the firm's replacement rate in the 1970s). On any of their regular 10-hour work days, top managers from the same departments can be observed talking with one another in hallways, elevators, parking lots, over the phone, and in the lobbies at headquarters. Most of these conversations last less than three minutes. Colleagues who do not share the same department tend to confine their communication to frequent (three of four per week) meetings, or, in the absence of meetings, had sparse interaction.

\section{The Executive Matrix}

Playco has eight departments-operations, research and development (hereafter R\&D), marketing, sales, finance, administration, engineering, and product planning-crosscut by seven product teams. This arrangement forms a product $\times$ function matrix (Davis and Lawrence 1977) in which product teams and functions are formally equal in decision making in the organization. The "office of the president" represents the highest reach of the executive ranks and has four offices: the presidents of domestic and international affairs, the chief executive officer (CEO), and the chairman of the board, who is infrequently involved with the daily affairs of the company. Departments contain two executive ranks: vice president and senior vice president.

Product teams are responsible for the company's products from conception to distribution. Some teams are responsible for a single product, such as a best-selling learning aid; other teams are responsible for an entire product line, such as games for children six to nine years old. Vice presidents of marketing are typically product team leaders, and one representative from each of the company's departments (except administration and finance) sits on each of the product teams. In most instances, 
executives fill out the membership of a product team, although "managers," the rank just below vice president, may also be included. Several factors determine the membership of product teams: an executive's reputation, task expertise, friendships with product team members and leaders, and individual interest in becoming a member of a particular team.

Playco vice presidents typically report to a senior vice president and a team leader. Senior vice presidents report to one of the presidents or to both a president and the chief executive officer, and they may sit on a product team in which they are also a "follower." An example of such a situation would be when a marketing vice president leads a team composed, among other executives, of a senior vice president of engineering or sales. Both of these situations create extremely uncertain lines of authority and can lead to conflict (see the next section for more information).

Similar ambiguities exist in executive evaluation. Although most top managers in business settings appear immune to close, standardized evaluation (Kanter 1977, p. 53), executives in the Playco matrix especially benefit in this regard. Their responsibilities often place them in formal structures with different standards and goals, a situation that creates differential allegiances in terms of authority and time commitments. Department heads, officially charged with the evaluation of their direct subordinates find it difficult to apply meaningful evaluative criteria.

These ambiguities were evident to some Playco executives when it first implemented its matrix in the mid-1970s following the participation by several of its executives in midcareer management programs at two graduate business schools. A long-time senior vice president remembered, "We had read about the matrix in Harvard Business Review and believed it might invigorate our top management; especially related to product development. So, a few of us went to an od [organizational development] seminar to learn about it. It sounded complex although it also sounded like we needed it." In fact, many executives initially resisted the matrix because of their perception of the uncertainty its dual authority would create. A vice president of administration recalls, "We had a hell of [a] time convincing our people to give it a try. What with the changes in industry going on, a lot of people thought they might lose their jobs; that the matrix would replace them or something. People wanted to hold on to their old ways of doing things. For the first couple of years, it was chaos. Nobody knew who to report to or who was responsible to whom. Everybody was really uncertain about the future."

One measure of the initial uncertainty faced by Playco executives in the matrix derives from files of the administration department containing "operating procedure" memos issued to executives about their new responsibilities in the matrix. In 1976, the first year of the matrix, 55 general memos were found detailing executive reporting lines and respon- 
sibilities. Many of the 58 general memos in 1977 corrected earlier memos regarding reporting authority and task responsibility. In each successive year such memos decreased gradually until memos along these lines ceased in early 1982 .

As Playco executives struggled inside the corporation to manage the uncertainty of their jobs, the American economy came to grips with significant changes in corporate acquisition practices. Hostile takeovers occur when "more than $50 \%$ of the shares of a large, publicly held corporation are purchased by another over the loud, public protestations of the target company's management, board of directors, and/or minority shareholders" (Hirsch 1986, p. 801). Playco engaged in several "friendly" takeovers (with the full knowledge and consent of shareholders and management of the target firms) and a few unsuccessful mergers; it also warded off two hostile takeovers and two friendly offers between 1975 and 1987. Executives at the firm considered friendly takeovers a legitimate business strategy, especially the way they "play the game." As the Playco chief executive officer put it, "We've worn white hats [as the good guys would in an Old West movie] in the takeover game. We're not [Carl] Ichan or Texas boys [in reference to particularly ruthless takeover entrepreneurs]. The firm has always been up front when going after [a takeover candidate]." Amid Playco's organizational and environmental changes, the ways executives framed their executive conflict management and the issues surrounding it also changed, as the next section demonstrates.

\section{EXECUTIVE CONFLICT MANAGEMENT PATTERNS: 1984-87}

\section{Conflict Issues}

Like managers in other organizations with matrix management (Butler 1973; Stinchcombe 1985), much of the conflict among top managers at Playco centers around issues of executive coordination and responsibility, or, in the words of the executives themselves, "who's supposed to do what, how soon, and where." Such conflicts typically involve differences in what executives term "vision" between product team leaders and department heads - the heads manage the demands of many product teams while product team leaders, in the words of a department head, "only worry about their products." In one situation, for example, a senior vice president leading a product team proposed a set of marketing goals that would eventually require significant modification of several of the company's manufacturing facilities. Several operations executives balked at the plan, claiming that the senior vice president had failed to take into consideration, as one vice president put it, "the real constraints of manufacturing and the time it takes to retool large assembly plants." 
The allocation of resources within the company, such as budgetary increases or decreases, office space, and personnel reductions or additions also fuel interpersonal tensions at the executive level. Most departments at headquarters, for example, share office space in the crowded, multistory "main tower." To consolidate their departments, many executives attempt to place subordinates with whom they most often work in offices near them. This practice prompts conflict as executives, trying to build similar spatial "empires," find themselves outflanked by their colleagues. Still other executives fume at personnel reductions, especially if they face increasingly difficult group goals but have fewer employees or smaller budgets to meet them.

The simple scheduling of meetings can cause executive conflict as well. Top managers often remarked during interviews about how "insulted" they felt when colleagues cancelled meetings without reasonable notice or simply did not attend scheduled meetings. One executive commented, "We waste more time around here trying to find meeting times. It takes a bozo to miss a meeting without calling."

Conflict sometimes occurs over what top managers term "ethical issues": the acceptance of gifts from suppliers or vendors, the fabrication of travel receipts, or pilfering from the company stores for private use. Conflicts also arise over executive style. One example concerned a president who frequently delivers "barbed quips" to his opponents at executive meetings. According to one top manager, "He has to learn to express his opinions, strongly, even if they are opposed to whatever is on the floor, and not be so sarcastic. He should treat his people [subordinates] more openly. But I guess it's just a defense mechanism. It's hard to be shot at when all there is to shoot is some quip you've thrown out." Some executives are also accused of "risk aversion," such as when a president criticized a senior vice president for his unwillingness to take the lead in a quality control program that might initially generate cost overruns for a new product, but could save the company millions of dollars in the long run.

Executives also regard the mixture of aggressiveness and excessive "emotional involvement" highly inappropriate. An executive nicknamed "the princess of power" illustrates this tendency. An informant explained that the princess of power sometimes violates executive etiquette: "Sometimes in meetings, she hammers at you, and gets real emotional about it; lets things get to a personal level. Most of the time she keeps it together. But you never know when she's going to red line, when things will get out of hand. It's one thing to be direct, to defend yourself in a strong manner, and quite another to be so emotional."

It is interesting as well to note what topics rarely cause executive conflict: gender issues related to fair treatment or hiring practices, legal 
consequences of company practices, idea stealing from colleagues for new products, and the quality or social value of new products. When these issues do become the bases for conflict, executives are especially prone to focus on how the principals pursue their grievances, rather than the substantive content of the disputes themselves.

\section{Honor among Executives}

Whatever the issues involved, Playco executives place great importance on personal reputation and public esteem in handling conflict with their colleagues-what they call an executive's "honor." At Playco, honor constitutes the core of managerial culture. Playco executives often speak of an executive's honor by reference to his or her "style," characterized as either "weak" or "strong," or whether they wear "white hats" or are "white knights," denoting their hero-like status. Less honorable executives are often referred to as "black hats" or "black knights," denoting a more deviant (in some cases, villainous) status. The origins of executive honor at Playco can be dated to the firm's first corporate acquisition in the mid-1970s. A senior vice president recounted, "Everyone [executives] seemed to be talking about [hostile] takeovers; white knights this and black knights that; how some takeover players played the game dirty [were not "up front" in their takeover bids]. The art of the takeover became big conversation at parties and at the office. . . We began talking about the "art" [using his hands to make quotations in the air] of the meeting, getting promoted, dealing with each other; especially fighting with each other. Now it consumes us." A top manager depicts the honorable Playco executive: "What is a strong executive, a guy who wears a white hat? A tough son of a bitch, a guy who's not afraid to shoot it out with someone he doesn't agree with; who knows how to play the game; to win and lose with honor and dignity."

And the "game" at Playco, like many codes of honor (Hoebel [1940] 1967 , p. 188; Bordieu 1965, p. 211; Rieder 1984, p. 138; Wyatt-Brown 1984 , p. 372), demands that challenges to one's decisions or behavior by worthy opponents be aggressively answered in a calculated fashion, and that one's colleagues recognize this concern for riposte. In this way, honor is, as Pitt-Rivers generally notes, the "value of a person in his own eyes, but also in the eyes of his society" $(1965$, p. 21). To be "honorable," then, means to follow a particular code of conduct and to have claim to the esteem of others and superiority over those who deviate from the code. At Playco honorable individuals and groups often translate their status into decision-making power and greater opportunities for gaining resources and building trust. The informal status conferred by executive honor thus displays less ambiguity than formal titles in the 
matrix. Highly honorable executives' statements at executive meetings (regardless of content) receive more respect and outward consideration by their colleagues than those of less honorable executives. Formally low-ranking but highly honorable executives are, as the executives say, "brought into" important decision-making processes by members of the office of the president. The company trusts those of great honor with the most sensitive executive tasks (such as negotiating with foreign governments about building manufacturing or distribution facilities). Honorable executives usually receive requested product team assignments. Executives even ask their highly honorable colleagues to facilitate executive conflict management. A 30-year veteran at the company commented on this aspect of honor among Playco executives: "Unless people [executives] see you have some notches on your gun, you're not going anywhere in this company. You can't back down here. You can't ambush people or shoot 'em in the back. Everyone knows real fast what color hat a manager wears in this organization."

Yet, task performance does not always translate into honor. A product team known as "the wild bunch" typifies this tendency as described by Playco's chief executive officer: "That team has been successful with our home computer lines, but they're a bunch of outlaws. . . . In what way? They don't understand how we do business at [Playco]. There are appropriate ways and inappropriate ways of fighting. The members of [the wild bunch] never learned that."

The subsections that follow analyze how Playco executives handle conflict. First, I examine conflict among honorable executives, then conflict among executives of lesser repute.

\section{Conflict Management among Honorable Executives}

The transformation of what Playco executives called conflict management "behind closed doors" during the 1970s into public contests of honor parallels the transformation of corporate acquisitions through symbolic imagery into a "high-stakes drama and spectator sport with a full panoply of characters cast as heroes and villains" (Hirsch 1986, p. 814). Playco executives generally use the imagery of "valiant efforts" and "failed gambits" to frame what they call "honorable" or "strong" conflict management. The Playco imagery used to describe honorable conflict also draws from the more respectful aspects of chivalry, the Old West, sports, and warfare genres, which are used in popular language to describe hostile takeovers and are also used at Playco in reference to the company's entertainment product lines. Table 1 presents a listing of the 
TABLE 1

Conflict Imagery and Corporate Takeover Imagery by Genre, Playco IMAGERY, AND TAKEOVER DERIVATION

\begin{tabular}{|c|c|c|}
\hline Genre & Playco Imagery & Takeover Derivation \\
\hline \multirow[t]{3}{*}{ Animals } & Dogs on a leash & $\ldots$ \\
\hline & Pigeon & Pigeon \\
\hline & Dog & Pigeon \\
\hline \multirow[t]{6}{*}{ Body/health } & Amnesia & $\ldots$ \\
\hline & Dick & $\ldots$ \\
\hline & Gas attack & $\ldots$ \\
\hline & Strong & $\ldots$ \\
\hline & Temporary amnesia & $\ldots$ \\
\hline & Weak & Pigeon \\
\hline \multirow[t]{10}{*}{ Chivalry } & Black knight & Black knight \\
\hline & Duel & Shoot-out \\
\hline & Executives in distress & $\ldots$ \\
\hline & Honorable & White knight \\
\hline & Princess of power & $\ldots$ \\
\hline & Second & $\ldots$ \\
\hline & Sleeping beauties & Sleeping beauties \\
\hline & Weak & Sleeping beauties/pigeon \\
\hline & White knight & White knight \\
\hline & Wizard & $\ldots$ \\
\hline \multirow[t]{4}{*}{ Nautical } & Jumping ship & $\ldots$ \\
\hline & Life vest & $\ldots$ \\
\hline & Pirate & Pirate \\
\hline & Raiding & Raiding \\
\hline \multirow[t]{5}{*}{ Relational/sexual } & Crying & $\ldots$ \\
\hline & Patched up & Wooing \\
\hline & Rape & Rape \\
\hline & Waltz around & Dancing \\
\hline & Withdrawal & $\ldots$ \\
\hline \multirow[t]{8}{*}{ Sports } & Blindsided & $\ldots$ \\
\hline & Cheap shots & $\ldots$ \\
\hline & Failed gambit & $\ldots$ \\
\hline & Hunting big game & Hunting big game \\
\hline & Playing the game & Ball is in play \\
\hline & Serious players & Takeover players \\
\hline & Target & Takeover target \\
\hline & Valiant effort & $\ldots$ \\
\hline \multirow[t]{2}{*}{ Science } & Meltdown & $\ldots$ \\
\hline & Red line & $\ldots$ \\
\hline \multirow[t]{6}{*}{ Warfare } & Burning fighter & $\ldots$ \\
\hline & Declare war & $\ldots$ \\
\hline & Killing an idea & $\ldots$ \\
\hline & Fight fire with fire & $\ldots$ \\
\hline & Flak vest & Flak \\
\hline & Flight deck & $\ldots$ \\
\hline
\end{tabular}


TABLE 1 (Continued)

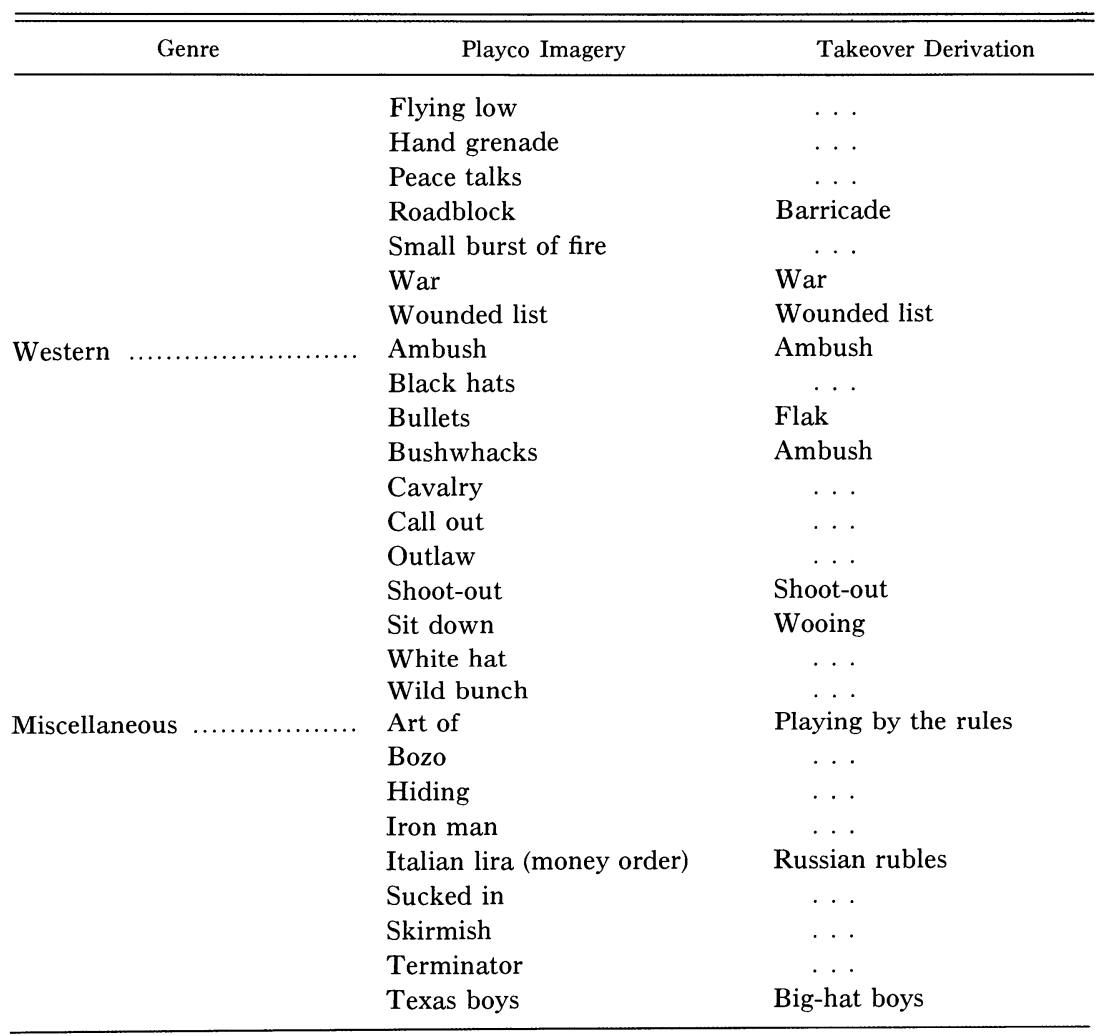

terms used by Playco executives sorted into genre groups and their takeover derivations. ${ }^{5}$ (App. B provides a detailed glossary of these terms.)

Behaviorally, Playco top managers pursue conflict with each other within the framework of a moralistic "tit for tat" (Rieder 1984, p. 133) or "reciprocal aggression" (Black 1990, p. 44) characteristic of vengeful conflict management among honorable disputants everywhere. As argued earlier, codes of honor generally specify the rules of challenge and riposte, including when, where, and with whom vengeance should occur. The social identity of an aggrieved party and the respective foe is particularly salient. Only weak subordinates, as several executives noted, back down from defending their decisions even when challenged by their superiors,

${ }^{5}$ Definitions of hostile takeover imagery in table 1 and in App. B derive from Hirsch and Andrews (1983) and Hirsch (1986). 
and only weak superiors fail to press their claims against recalcitrant subordinates-at least until compromising with them. To protect or advance one's honor, only worthy opponents can be challenged or responded to in a dispute. This prerequisite assumes that the principals recognize each other as honorable (and are aware of their overall reputations in the company), and that with the exception of intradepartmental conflict (discussed below), top managers wait until a strategic public occasion to issue their challenges or responses. Worthy opponents therefore know and follow the rules of the game, generally play well (even if they lose), and abide and accept the consequences of their outcomes. Those who do not play the game well are to be avoided lest they contaminate the reputation of honorable and higher status executives. Table 2 presents the processual character of honorable conflict management and the quantitative distribution of these forms across three important contexts in which they occur at Playco: within departments, within product teams but between principals of different departments, and between principals of neither the same department nor the same product team.

Although reputations are mutable at Playco, early labeling as a "black hat" tends to follow an executive throughout his or her career at the firm. In this sense, one's initial reputation can act as a self-fulfilling prophecy. Behaviors one would find unusual in honorable executives, such as emotional outbursts or covert action, come to be expected from dishonorable Playco executives. Even behavior identical in both honorable and less honorable disputes, for example, arguing, carries with it different labels reflecting the status of the disputants. Arguments are "skirmishes" among honorable executives and "cat fights" among less honorable top managers. At the same time, honorable executives enjoy a certain leeway in explaining and having their behavior explained should they deviate from the code of honor.

If honor provides the overarching rules of the game for Playco executive disputes, the social distance between honorable disputants determines how those rules are applied in particular cases. Social distance generally increases the aggression between principals (defined here as the degree to which a disputant attempts to achieve a desired outcome at the expense of an adversary), the length of disputes, and their scope in terms of the number of individuals involved (on this general effect, see Koch [1974, pp. 91-158]; Rieder 1984, pp. 146-48). Where the principals are more socially intimate, such as in the situation of departmental colleagues, the reciprocity of their actions is less exact, less controlled, but also less aggressive and more likely to end in a mutually agreeable outcome. Conflicts among departmental colleagues not only weaken departmental solidarity, which may be crucial in interdepartmental feuds, but also threaten the department's collective honor, so important in main- 
TABLE 2

Conflict Management among Honorable Executives

\begin{tabular}{|c|c|c|c|}
\hline $\begin{array}{l}\text { Work-Unit Membership } \\
\text { of Principals }\end{array}$ & $\begin{array}{c}\text { Initial } \\
\text { Exchanges }\end{array}$ & $\begin{array}{l}\text { Secondary } \\
\text { Exchanges }\end{array}$ & $\begin{array}{l}\text { Probable } \\
\text { Outcomes }\end{array}$ \\
\hline $\begin{array}{l}\text { Same department } \\
\quad \text { (case 1) }\end{array}$ & Skirmish & Sit down & Patch up \\
\hline $\begin{array}{l}\text { Same product team } \\
\quad \text { (case } 2)\end{array}$ & Call outs & Duel/shoot-out & $\begin{array}{l}\text { Withdrawal } \\
\text { Patch up } \\
\text { Rescue by a white knight }\end{array}$ \\
\hline $\begin{array}{l}\text { Neither product team } \\
\text { nor department } \\
\text { (case 3) }\end{array}$ & $\begin{array}{l}\text { Call outs } \\
\text { Hand grenades }\end{array}$ & War & $\begin{array}{l}\text { War } \\
\text { Rescue by a white knight } \\
\text { Peace talks } \\
\text { Jumping ship }\end{array}$ \\
\hline
\end{tabular}

Note. - For case-1 types, $n=7$; for case-2 types, $n=11$; for case- 3 types, $n=6 . N=24$. For definitions of terms, see App. B.

taining its status relative to other departments. For these reasons, departmental colleagues (especially department heads) always attempt to prevent a dispute from escalating beyond the private confines of their department. Because of the ambiguities in command created by the matrix, departmental colleagues' influence remains limited to persuasion. Such persuasion is most effective when departmental colleagues have offices near one another, where they can use their intimacy as a resource with one or the other principal. Social distance also affects the imagery used by principals in framing conflict management. More intimate principals tend to use less imagery in describing their own and their opponent's actions, and what imagery they use is less aggressive than that used for interdepartmental conflict. The narrative below offers a representative illustration of the intradepartmental conflict management pattern in table 2. It begins with an argument between the principals. ${ }^{6}$ Rather than escalating into a more aggressive pattern, the principals negotiated a compromise to their conflict.

Case 1: The gifted vice presidents.--Representing Playco in dealings with foreign companies is always tricky business. In one instance, two highly regarded operations vice presidents, Spelling and Roberts, received gifts from a supplier during a trip to the supplier's Southeast Asian country. The gifts, intended to strengthen the relationship between

${ }^{6}$ Cases selected for presentation were chosen because of their representativeness of individual-level behaviors and patterns of conflict management among Playco executives. All nicknames and titles specific to Playco executives were changed to protect the anonymity of those involved. Product team responsibilities and some incidents were also altered to protect the anonymity of Playco executives. 
Playco and the supplier, included expensive jade jewelry for the VPs' wives and Rolex watches for themselves. Spelling and Roberts knew they would have an argument with their senior vice president, Turner, over accepting the gifts. Yet, as Roberts pointed out, "We took a greater risk not taking them and losing face with [the supplier]." The vice presidents also knew Turner would take a strong stance in handling the matter because he wears one of the "whitest hats" in the firm. An argument did erupt between Spelling and Roberts and Turner when they told him of accepting the gifts. Turner demanded they return them, claiming they had put the company at legal risk. The principals in this case were quite confident that their colleagues recognized the ambiguities of doing business abroad and at the very least the information would not escape the organization in any traceable way to legal authorities. They were more concerned that the department not be viewed, in their words, as weak and torn by indecision. After talking with departmental colleagues about the importance of resolving their dispute, the principals had a "sit down" to "patch things up." Turner agreed to visit the country and meet with Playco's suppliers. Until then, Spelling and Roberts would refrain from accepting any more gifts from suppliers.

Interdepartmental cases exhibit the ritualistic nature of Playco executive conflict management more clearly. Case 2, for example, illustrates what Playco managers refer to as "meeting duels" before which the principals punctuate their challenges and ripostes with more patience and what Rieder (1984, p. 145) observes in general for honorable conflict management as "a quality of calculation . . . the wily sizing up of a rival's mettle" during which the disputants argue until their proposals or ideas are, as the executives say, "killed" and the bearer of the vanquished idea "withdraws." The case recounted below illustrates interdepartmental/product team conflict and also underscores an important principle among Playco executives: The way an executive wins is as important as the way he or she loses. Victors rarely claim complete defeat of an opponent. To do so would be to insult the honor of the vanquished and, in the process, do dishonor to themselves. Even executives who do not win, but who play by the rules, maintain a part of their reputations and can more easily restore their honor in a future contest. At the same time the imagery used by executives to frame interdepartmental disputes versus that used in intradepartmental conflicts is more aggressive. Such variation conforms to the aggressive imagery used to describe socially distant actors relative to the business mainstream in highly publicized hostile takeovers (Hirsch 1986) and generally by international disputants to describe socially distant opponents (White 1965).

Case 2: The target date duel.-Executives on the same product team often split into smaller groups to decide issues relevant to the team as a 
whole. Three executives (the marketing team leader, Harris, and the executive representatives from $\mathrm{R} \& \mathrm{D}$, West, and sales, Holmes) decided to meet separately from their team to devise a set of target dates for the development of a new set of products. West agreed to arrange meetings with Harris and Holmes and attempted to do so over a three-week period. Each time he scheduled a meeting, either Harris or Holmes cancelled at the last minute. In the meantime, West quietly gathered the data necessary to organize the plan by himself because he knew he "was dealing with a couple of the strongest people on the product team and he had to be ready if they proposed their own plan." He announced at a regular team meeting he would not be caught by surprise by his colleagues and would put together a plan of his own. Facing Harris in the meeting, West announced that he would have nothing to do with a plan proposed by her or Holmes if, as he phrased it, "they had the balls to talk." Harris and Holmes decided that they might be able to "put some notches in their own guns if they shot [West's] proposal down." Harris responded to West's challenge by walking to his office the day after the meeting and, in the middle of a meeting between him and three other managers, told West "that they [Harris and Holmes] were insulted that he had gone ahead without their participation, and would present a plan of their own." These challenges and counterchallenges indicated a "duel" would occur at the next team meeting. Besides carefully preparing their presentations, each of the principals prepared themselves through rituals common in such situations. All of the principals wore their lucky ties and "flack vests" (uncommonly worn on a day-to-day basis) to fend off "bullets" from the opposition. They all spent extra time at their respective health clubs: taking more time in the sauna, and each having a massage. They also spent considerable time talking to their departmental colleagues about how they would comport themselves during the presentation. The rest of the team knew of the "duel" via an agenda circulated three days prior to the meeting. As was customary, an uninvolved team member spun a gold ballpoint pen flat on the meeting table; the principal to whom the ink end pointed being allowed to chose the order of presentation. The pen pointed toward West, who elected to present last. Holmes acted as Harris's "second" by handing out copies of the plan to team members and handling all of the visual aids. West used an R\&D middle manager as his second. At the conclusion of each presentation, West and Harris began a give and take of questions, criticisms, and rebuttals, each careful not to interrupt the other. During this part of the duel, Harris's rebuttals and criticisms grew weaker until she sat mute in response to two lengthy questions by West. West, on the other hand, grew stronger; his criticisms and rebuttals to Harris became more authoritative each time he spoke. The other team members remained silent until, as the 
operations representative put it, "the jousting concluded." In the aftermath of her two-minute silence to West's final points, Harris tore up her copy of her's and Holmes's plan signaling her acceptance of West's plan. Holmes then collected their copies of the plans from the rest of the team, and instructed a secretary to feed them into a paper shredder. After the meeting, the combatants ritualistically shook hands. During this duel, none of the other team members spoke until after it concluded, at which time, the meeting moved on to other agenda items. Later, West said to the observer that, although the team had not accepted his colleagues' plan, Harris and Holmes answered his challenge "strongly." "After all," he concluded, "they're strong players. They couldn't just sit there and do nothing after I called them out."

In disputes between principals who do not work in the same product team but reside in "strong" departments, matters that might seem trivial to an outsider - the remodeling of one wing of corporate headquarters, whether the company should fly the flags of representatives of foreign governments when they visit a company installation, and the location of assigned parking places for executive secretaries-may escalate into a collective feud between departments and their allies. In all of these cases, the lack of social links between the disputing departments means there is little social pressure to end hostilities and great social pressure to attack in honorable ways. Executives therefore find it nearly impossible to end interdepartmental conflicts without the aid of third parties who intervene to bring about some sort of settlement (white knights who "rescue" executives "in distress"). Here again the matrix weakens the ability of third parties to constrain or resolve hostilities because of ambiguous and overlapping chains of formal authority. As in intradepartmental conflict, such intervention is limited to persuasion.

Third-party supporters, however, may have the opposite effect on interdepartmental disputes, spreading them to many departments and product teams. The solidarity among marketing and operations executives, for example, engenders the expectation of automatic partisanship in interdepartmental conflict involving one of their own. In less cohesive units, such as sales, partisanship is highly tenuous, and defections to the opposition are not uncommon. Case 3 illustrates the modal patterns of conflict management among executives who do not work in the same unit and who work in departments with staunch allies.

Case 3: The marketing plan feud.-Executives at Playco earn colorful nicknames, such as the aforementioned "princess of power" in marketing, as well as "iron man" in operations, and "the wizard" in R\&D. Early one calendar year, the princess of power became the head of marketing and introduced a new general marketing plan for the company. Playco traditionally concentrates its production in a five-month period. 
With several months of marketing surveys showing Playco's home computer products leading the way, the princess of power wanted to extend production to nine months per year to capitalize on expanding markets in Australia, Southeast Asia, and Europe. As head of operations, iron man believed this plan would jeopardize the quality control systems he had personally championed in the company's manufacturing facilities, systems that had become industry standards. The princess of power and iron man had never sat on a product team together, so when they met twice with members of the office of the president to discuss the ninemonth plan, they spent most of their time, as iron man observed, "simply trying to understand each other." At some point in these meetings, iron man became annoyed with what he called the princess of power's "small bursts of fire" about operations' lack of support for the marketing plan. He felt that she treated him like a "horse put out to pasture who didn't know a demand function from a hole in the ground," while "she did not understand, nor want to understand what the hard constraints on manufacturing related to quality were." The princess of power believed iron man was "inflexible" and "out of touch with the direction the company had to go." At two subsequent meetings the principals exchanged very direct complaints along the lines described above. By the fourth meeting, the princess had grown tired of iron man's "roadblocks" and, in her words, "carefully questioned whether [iron man's] questions were in the company's own interests or his own." Iron man waited several minutes until the princess had finished her complaints about his reactions to the plan. He then stood up and, in his words, "threw her a couple of hand grenades by looking her in the eye and saying that [he] would not allow her to kill every idea he brought up in public." The princess then stood up and said, "If you want a war, fine." The ensuing months witnessed the outbreak of war between operations and marketing and their supporters: several presentation shoot-outs and duels between marketing and operations executives and managers as well as the mobilization of members of other departments on behalf of the principal departments. During the dispute, the vice president of administration, Johnson, known as a white knight who rescued executives in distress, intervened with two other white knights-the president of international affairs, Sims, and the wizard-to reduce the "wounded list." These attempts proved initially unsuccessful, but eventually resulted in a two day off-site set of "peace talks" which nearly 30 executives and managers attended. The meetings produced a truce between the factions and a private dinner between iron man and the princess at which, according to Johnson, "they agreed they disagreed on a variety of matters."

While these analyses and illustrative cases portray the modal realities of conflict management among Playco executives, there is, as the Playco 
TABLE 3

Conflict Management among Less Honorable Executives

\begin{tabular}{|c|c|c|c|}
\hline $\begin{array}{l}\text { Work-Unit Membership } \\
\text { of Principals }\end{array}$ & $\begin{array}{c}\text { Initial } \\
\text { Exchanges }\end{array}$ & $\begin{array}{l}\text { Secondary } \\
\text { Exchanges }\end{array}$ & $\begin{array}{l}\text { Probable } \\
\text { Outcomes }\end{array}$ \\
\hline $\begin{array}{l}\text { Same department } \\
\quad \text { (case } 4)\end{array}$ & $\begin{array}{l}\text { Flying low } \\
\text { Cat fight }\end{array}$ & $\begin{array}{l}\text { Flying low } \\
\text { Hiding } \\
\text { Red lining }\end{array}$ & $\begin{array}{l}\text { Amnesia } \\
\text { Jumping ship } \\
\text { Vaporized }\end{array}$ \\
\hline $\begin{array}{l}\text { Same product team } \\
\quad \text { (case } 5)\end{array}$ & Waltzing around & $\begin{array}{l}\text { Temporary amnesia } \\
\text { Gas } \\
\text { Crying } \\
\text { Hiding } \\
\text { Meltdown }\end{array}$ & $\begin{array}{l}\text { Amnesia } \\
\text { Jumping ship }\end{array}$ \\
\hline $\begin{array}{l}\text { Neither product team } \\
\text { nor department } \\
\text { (case 6) }\end{array}$ & Call out & $\begin{array}{l}\text { Temporary amnesia } \\
\text { Crying } \\
\text { Bushwack/ambush/raid }\end{array}$ & $\begin{array}{l}\text { Amnesia } \\
\text { Jumping ship }\end{array}$ \\
\hline
\end{tabular}

Note. -For case-4 types, $n=5$; for case-5 types, $n=6$; for case-6 types, $n=4 . N=15$. For definitions of terms, see App. B.

managers say, a "seamier side" to political life at the top of the corporation that involves only those executives labeled as weak.

\section{Conflict Management among Less Honorable Executives}

Less honorable executives most clearly indicate their lower status by not responding at all or responding in inappropriate ways to grievances by colleagues. They allow colleagues to verbally "rape" them, simply tolerate their opponents by "flying low," participate in covert action to inconvenience opposition departments through "raids," or avoid inflamed conflicts by "parachuting out of burning fighters" (when they should see them to their end and "ride them down"). Table 3 contains the patterns of conflict that are labeled "less honorable" by Playco executives.

The imagery of conflict used by executives to describe the conflict management among less honorable executives also highlights that group's violations of the code of honor at Playco. Whereas honorable colleagues portray their opponents in worthy lights by referring to them as white hats or serious players, less honorable executives talk about their adversaries as "dicks" or "sleeping beauties." Moreover, honorable executives commonly label their less honorable departmental colleagues as "pigeons" or "bozos" and their arguments as "cat fights" rather than the more value-neutral "skirmish."

The intradepartmental patterns of executives labeled as less honorable are illustrated in case 4 below. It should be noted that Playco executives 
do not deplore fighting between executives. Rather, they deplore it when it is outside the boundaries of the code of honor. During fieldwork for example, two boxing matches were arranged between executives at a local gym in order that they might, as one executive observed, "work out their differences." Case 4 involves executives whose long-standing, unexpressed grievances unpredictably escalated from a public argument to scuffling, and eventually to the resignation of one principal.

Case 4: Red lining in the parking lot.-A vice president of sales liked to think of himself as, and liked others to call him, "the terminator" because, as he put it, "[he] hunts big game anyway he can [looks for honorable opponents whom he can best in conflict]." According to several Playco executives, the terminator's track record was not as good as he liked to think, and he frequently allowed the strongest executives to rape him in meetings. When he did retaliate, he did so by attacking pigeons. The terminator and his senior vice president, Greer, each believed the other to be dicks but flew low in not expressing their grievances. One morning, while employees streamed into Playco's main parking lot, the terminator was unloading briefcases from the trunk of his car when Greer eased past in his car and asked to see the terminator in his office later that day. After Greer parked his car, the terminator walked over to his car and said, "Hey, I'm not your dog. What the hell do you want to see me for now?" As the two men argued, other issues surfaced, including the terminator's open "womanizing" with company secretaries and with married women at a local health club to which many Playco executives belonged. The cat fight quickly "red lined" whereupon Greer shoved the terminator against the trunk of his Lotus sports car. The terminator then grabbed Greer and pushed him to the pavement. A crowd of employees gathered to watch the melee, and as company security officers arrived on the scene, Greer threatened to "vaporize" the terminator. Although outward pressure from Greer was not evident, the terminator "jumped ship" several weeks later.

Social distance has the same general effects on conflict management among less honorable top managers as it does on their honorable colleagues. Intradepartmental conflict among less honorable executives is less aggressive, is shorter, and has a narrower scope than that which occurs interdepartmentally. The imagery used by less honorable disputants to describe socially distant opponents is also more aggressive (in the sense that the principals attempt to garner zero-sum wins with their opponents). Case 5 illustrates interdepartmental conflict between less honorable executives. Note that this case begins in a similar fashion as one might between two honorable executives. However, it quickly evolves into several nonverbal grievance exchanges, including "temporary amnesia" by one principal of the other's complaints, "crying" about 
the conflict by both principals to confidants, "hiding" by one principal to avoid the other, and finally a "meltdown."

Case 5: The wild bunch. - The wild bunch is a product team responsible for computer learning aids for children. In one situation, planning vice president Pound believed operations vice president Ingle to be unsuitable to present their team's new products at what Playco managers termed a product send-off (presentations attended by hundreds of Playco employees to preview new products before they go into production). At two weekly team meetings, Pound and Ingle "waltzed around" about the latter's suitability to present. At a third meeting the following week, Ingle turned away from his colleague and noticeably frowned as though he had a "gas attack" to a team member sitting on his other side. $\mathrm{He}$ then interrupted Pound in midsentence with a loud, lengthy comment. Subsequently, both Pound and Ingle went crying to friends, but never confronted each other. Pound hid from team meetings for two weeks because, as he put it, "he couldn't stand to be in the same room as that dick [Ingle]." Rumors began in the company that Pound feared confronting Ingle. Two weeks after the initial incident, at another team meeting, Ingle interrupted Pound loudly again and Pound responded by raking his hand across the burgundy teak meeting table, pushing his and two other colleagues' materials to the carpet. Pound and Ingle then had a meltdown by pushing each other and swinging their fists. The meltdown lasted several minutes, spilling out into the hallway where a security guard watched for two or three minutes before breaking it up. Inside the meeting room, two colleagues continued talking about another issue, and two others were laughing. The principals suffered several bruises and clothing tears. Word of the fight quickly spread through the company. Pound commented in the aftermath that he "couldn't let that dick [Ingle] get away with pretending not to listen to me again."

Whereas honorable disputants can mobilize departmental and crossdepartmental allies to attack enemies through meeting duels, less honorable executives command neither the loyalty nor the trust to do the same. The scope of less honorable executive conflict management enlarges in unpredictable ways as executives become allies ("sucked in") because, for example, they happen to work in the physical proximity of a feud. Respectable third parties do not generally intervene to settle such disputes either, because of the same trepidation one would have, an executive noted, in intervening into a fight between rabid dogs: "You never know what's going to happen, even if it's your own dog. You could get bit yourself." The narrative below illustrates this process. Note that it begins with a "call out" (as in interdepartmental conflicts between honorable executives). Yet its path deviates from the honorable way when the principals engage in numerous covert actions ("raids," "ambushes," and 
"bushwhacks") against each other and allow their grievances to peter out as they tire of the conflict without a public and ritualistic resolution.

Case 6: The finance raid. - Two of the executives known for their covert conflict management (who wear the black hats in the firm), Bell, the chief financial officer and, Tweedle, the president of domestic affairs, became embittered over Tweedle's attempt to transfer Hicks, a finance vice president, to engineering to create a new position: vice president of engineering cost control. Financial executives do not meet regularly with product teams but are ultimately responsible for all cost control. Tweedle viewed the transfer as an experimental attempt to integrate finance with the product teams. Hicks would remain a member of finance, have an office in engineering, and meet, when appropriate, with one or two product teams. Bell believed Tweedle had ulterior motives: "This is a chicken shit ambush on my decision power in corporate financial affairs. [Tweedle] tried to do this last year by taking more formal control for the domestic budget. Now this. [Hicks] would end up reporting to [Tweedle]." Bell called out Tweedle at a meeting of the office of the presidents to "lay out his whole strategy for integrating finance into the product teams." Tweedle did not respond at the meeting or subsequently, suffering temporary amnesia by denying to close colleagues that there was any problem between him and Bell. Hicks's reassignment occurred as Tweedle planned. In the ensuing months, Tweedle ignored Bell's many memos questioning the transfer and spread rumors that he and Bell had worked out an agreement for Hicks's transfer and that Bell's word was worth as much as an "Italian lira money order" and perhaps he "did not have all his dogs on one leash." The dispute escalated during remodeling at headquarters when Tweedle approved plans for temporarily moving finance executives to a building adjacent to the executive "flight deck." Without notifying finance, the move occurred on a weekend. When finance executives arrived the following Monday, they discovered the move and that several important computer tapes and data printouts from an internal audit they had just completed had been thrown away. Tweedle knew that Bell had personally championed the now-disrupted audit. Speculation ran high in the company that Tweedle had involved himself directly in throwing away the data when he had stopped by headquarters for two hours during the move. Tweedle expressed his temporary amnesia by maintaining that he had nothing against finance, although he admitted to some that the move would upset the "sleeping beauties in finance" who were believed to be enamored with their own abilities but ignorant of their negative reputation among other top managers. Bell stopped his memo writing for two weeks following this incident as his staff attempted to reconstruct the data from older, backup tapes. In the meantime, Bell suspended all financial data reports to teams developing 
domestic products. Bushwhacks such as these continued for nearly two years until Tweedle and Bell tired of the battle. Tweedle and Bell eventually jumped ship. Hicks now occupies the chief financial officer's position.

\section{DISCUSSION AND IMPLICATIONS}

One could argue that Playco's growth into a multinational corporation during the 1970s, and its high product replacement rate (which decreased in the 1980s), could also have led to the observed conflict patterns. One could also argue that the imagery Playco executives use to frame their conflicts derive solely from their products lines: games and learning aids that encompass the themes of chivalrous duels, Old West shoot-outs, and science fiction warfare. Indeed, only 30 of 72 Playco conflict images derive directly from hostile takeover imagery (see table 1). Yet, the very same themes in these product lines-the "bread and butter" of the firm, as one executive put it, for over 30 years-existed prior to the firm's restructuring with the matrix and the advent of the hostile takeover. Despite all of these factors, the culture of honor among Playco executives did not exist until the 1980s. Conflict management prior to the 1980 s resembled the placid scenes offered by Kanter (1977) and Moore (1962). Thus, many of the local symbols that Playco executives draw on to linguistically frame their conflict into contests of honor existed, but they did not have a plausibility structure associated with them until the transformations brought about by the matrix. By the same token, the imagery of the hostile takeover would not have had the impact on executives if it did not coexist with the particular plausibility structure at Playco. If the language of the hostile takeover represents the institutionalization of a symbolic dimension of a macro social change in intercorporate American business (Hirsch 1986, p. 821), the experience of executives at Playco illustrates the impact of symbolic and structural dimensions of matrix structures and hostile takeovers inside corporations. It is first to the plausibility structure of Playco honor that I now turn, and I follow with an examination of the consequences of Playco honor at the organizational and individual levels. I conclude with speculative implications of intracorporate executive honor and vengeance for the study of executive inertia, control, accountability, and theoretical approaches to firms.

\section{The Plausibility Structure of Honorable Vengeance}

Black, drawing from cross-cultural studies of conflict management, argues that highly predictable and ritualized conflict management framed by codes of honor is common among relatively equal disputants who have 
sustained mutual access to each other and who have standing groups of supporters they can easily mobilize on their behalf, but who are not socially intimate or functionally interdependent (Black 1990, pp. 44-47). Taken together, these variables operate as a "value-added model" (Smelser 1962, p. 14) that constrains disputants' choices of conflict management. The more a setting contains these social characteristics, the more likely it will contain a predominance of reciprocal conflict management-vengeance-ordered by codes of honor (Black 1990, p. 62).

Equality (in terms of resources and authority) means that disputants are constantly struggling for some sort of symbolic capital vis-à-vis their opponents. This induces the swift address of affronts by a challenger lest one gain an inferior reputation (Peristiany 1965). Egalitarian settings also contain few third parties who command the resources or deference necessary to settle disputes. Those third parties that do exist in such contexts typically rely upon their personal influence over the parties to suspend their hostilities. Conflicts are therefore rarely transformed from dyadic confrontations between principals to triadic settlement processes (Koch 1974). Where standing groups exist, the risks of confrontation can be syndicated across group members. As a result, groups, rather than individuals, may be even more willing to openly reciprocate grievances against opponents (Thoden van Velzen and Watering 1960). Finally, relational distance and functional independence reduce the likelihood of common interests (especially exchange relations), which both disputants may want to protect and which can engender more restrained conflict management (Colson 1953; Gluckman [1956] 1967).

Playco executives experience all of these conditions to some degree as they navigate their matrix and departmental authority systems. As described earlier, Playco top managers find themselves in a relatively egalitarian system: the crosscutting authority in the matrix and departmental hierarchies tend to cancel each other out. The uppermost levels of the corporation, the office of the president, contains four top managers of relatively equal formal status and with complex and ambiguous reporting lines to their subordinates. Thus, even at the top of the corporation, the possibility of third-party settlement is highly constrained. Executives also have easy access to each other by being housed in the same building and by attending frequent meetings with each other. Yet, most executives still tend to confine their informal interaction to departmental colleagues, reserving much of their interdepartmental interaction to formal meetings. When executives speak of the necessity of informational interdependence among colleagues, they primarily refer to that among their intradepartmental colleagues. Many executives, therefore, can call upon departmental colleagues as allies in disputes and other affairs. The fact that more ritualized challenges and ripostes occur in interdepartmen- 
tal conflict conforms to general propositions that relational distance, functional independence, and a high capacity for collective action are found whenever disputants engage in honorable vengeance. Also found in settings where honor is the symbolic currency of conflict is behavioral predictability at the individual and social organizational levels.

\section{Small Wins and Individual Uncertainty}

In a world where the corporation could be "taken over at any minute," as one Playco top manager put it, in which corporations are increasingly restructuring their operations, executives realize their substantive decisions can become instantly meaningless because of the actions of unknown investors or shareholders. One of Playco's presidents commented that "to worry about a single decision and how it's going to affect the firm is foolish. We can't really control what the market does, what the shareholders do, or what some yahoo investor with big money wants to do [in the case of a hostile takeover]. So you might as well try to affect the things closest to you."

In social psychological terms such behavior tacitly adopts the strategy of "small wins . . controllable opportunities that produce visible results" (Weick 1984, p. 43). Actual restructuring and its threat in companies that have experienced takeovers has eroded organizational loyalty to the point where small win strategies often manifest themselves as "managerial free agency" (Hirsch 1987, pp. 107-18): a lack of focus on corporate goals and the continual consideration of viable employment with organizations other than one's own. Playco executives breathe the air of takeovers, have witnessed their effects on companies that have been so acquired, but have successfully fended off takeover attempts themselves. Although Playco executives have not experienced high turnover rates, as indicated by the majority of their lengthy tenures with the firm, they have adapted to this increasing nihilism toward corporate loyalty by focusing on their own fates as expressed ritualistically through small-win strategies in their culture of honor.

\section{Social Similarity and Organizational Uncertainty}

Honor not only allows individuals to maintain a sense of balance and efficacy within the volatility of American business, it also operates as an organizational culture control in terms of social similarity. Social similarity subtly functions to reduce the uncertainty inherent in the discretionary nature of executive jobs (Kanter 1977). Executives tend to hire people who are socially similar to themselves in terms of ethnicity, education, class background, and gender to fill top managerial posts in order to 
assure some predictability and trust in their behavior (Kanter 1977, p. 53).

The functions of social similarity persist among Playco executives through executive honor. Playco's code of honor defines a particular "masculine" standard to which viable members of its relevant community must adhere. Like codes of honor everywhere, it is the key link between self and community, defining appropriate institutional roles (Berger, Berger, and Kellner 1973, p. 86). Honor at Playco defines who is to be trusted; it helps executives predict what their colleagues will do in a setting that might otherwise seem like a maelstrom of ambiguous authority and continual confrontation. The unnerving experience of conflict is framed as a contest of honor with the roles of the principals and their supporters carefully defined. Honor therefore provides an evaluative criterion for executives that operates outside of the official criteria but one that executives can more easily use in dealing with colleagues. In this way, the fetishism of honor among Playco executives orders their goal-directed behavior.

This is why less honorable executives are avoided by their honorable colleagues. Playco executives fear the unpredictability of their less honorable colleagues far more than the familiar challenges of their honorable colleagues. In one way, less honorable executives possess a more valuable form of capital than their honorable colleagues: unpredictability. Yet, in imperfectly imitating the routine conflict management of their honorable colleagues, less honorable executives ironically become impotent in transforming this capital into power by framing their behavior in relatively predictable patterns.

\section{Implications of Intracorporate Honor}

The foregoing analysis suggests several hypotheses to explain top managerial behavior in economic organizations. The first three of these are directly grounded in the Playco case, while the last two are more speculative in nature.

1. Reputation and honor ceremonies provide stability and predictability in an intraorganizational context of high uncertainty and ambiguity. This hypothesis summarizes the functions of reputation and honor ceremonies among Playco executives discussed above. However, this hypothesis is not offered without a consideration of how power and control enters into the use of ritualized conflict by executives. Hypotheses 2 and 3 directly consider these implications.

2. Intracorporate reputation and honor ceremonies can be sources of control and information for top managers over their executive subordinates. This implication is suggested by Eccles's (1985) arguments that 
managerial conflict among subordinates can be used by superiors as a source of information, thus increasing their ability to control, subtly, subordinate behavior. Control can also result from managerial conflict as managers police each others' actions, ensuring, as Eccles (1985, p. 215) argues, that "both are using resources as efficiently and effectively as possible." The public nature of the art of honorable vengeance makes it a perfect source of information for top management at Playco. The chief executive officer, for example, noted that he need not practice Peters and Watterman's (1982) "management by walking around" because information abounded in considering winners and losers in recent managerial duels. The fact that Playco executives gauge reputations in order to appropriately challenge their colleagues and respond to challenges also ensures a great deal of mutual monitoring.

The empirical materials presented in this paper, however, also suggest that the control/information approach can cut several ways. Benefits from conflict and intracorporate vengeance in particular depend on three crucial issues. First, such benefits will result only if executives are driven not only by conflict games but also by substantive issues of importance to the health of their organization. At Playco, ritualized conflict games mean a great deal to executives aside from the substantive issues at stake. Consider, for example, the importance stressed by the participants in cases 1-3 on how they fought their conflicts, how they would be perceived by their colleagues, and whether they won, rather than on what they fought about. In cases 4-6, winning was the only thing, to quote Vince Lombardi's old cliché; the standards of the game, much less its content, were not paramount to its participants. As a result, it is unclear what kinds of standards the participants will uphold among each other in executive settings conducive to intracorporate honor and vengeancestandards related to the game itself or those related to bottom-line efficiency however measured.

Second, the amount of public conflict (as suggested in remarks by Playco executives comparing mid-1980s conflict management at the firm with that which occurred in the mid-1970s) may lead to further uncertainty and even a sense of powerlessness by top management. The complexities of crosscutting authority relations at the executive levels may constrain translating knowledge of executive activities into timely action. Moreover, members of the office of the president are sometimes constrained to act on the information they garner lest they become involved in a protracted and potentially damaging (to their honor) conflict.

Finally, the informational and control benefits of intracorporate, honorable vengeance depends upon whose perspective one takes in assigning its costs and returns. The office of the president at Playco may benefit from the public nature of conflict in the culture of honor. At the same 
time, the benefits to the participants of vengeance is harder to assess. Certainly, one may gain skills at managing conflict in an "honorable" way. If the diffusion of matrix forms and hostile takeovers have created similar conditions in other large firms, then these skills may have some transferability. This is an open question beyond the scope of this article. However, the ethnography suggests that some executives thrive in the world of challenges and ripostes at Playco, while others find it difficult to perform their duties because, as one vice president put it, they "were always looking over their shoulder."

3. Intracorporate reputation and honor ceremonies act as a check on the obfuscation of accountability in executive decision making created by the matrix and the language and practices associated with hostile takeovers. This implication relates to 2 above but with specific ties to executive accountability in decision making. Matrix systems promote the syndication of risk by entire executive corps as groups of high-level managers embedded in complex authority relations are responsible for decision making rather than individual managers. In such a structure, it is difficult to trace decisions to any one manager; most decisions must be traced to some group process within or between product teams or departments. Hostile takeovers similarly obfuscate managerial accountability by creating ambiguous lines of corporate control from executives to their own corporation. The turbulent sea of hostile takeovers provides executives with convenient fall guys for poor decision making-stockholders, boards of directors, unknown corporate raiders-all of whom, in a broad sense, syndicate the risk of decision making for corporate executives. Honorable vengeance provides one check on this because of its public nature. The necessity of maintaining one's honor within the corporation requires executives to tout their own prowess at vanquishing opponents, thus making themselves more visible as principals in decisional outcomes.

4. Over time, the negative reciprocity engendered in matrix systems tends to increase internal organizational inertia. Scholars and practitioners have long argued that matrix management is extremely difficult to implement (Davis and Lawrence 1977). Less often discussed is the process of changing a matrix system to another kind of managerial structure (such as back to a unitary command structure). Black (1990, p. 47) calls the social setting in which vengeance persists a "stable agglomeration" because its participants are often "frozen" together in endless patterns of negative reciprocity framed by honor. Such a scenario captures the behavioral patterns at Playco. Playco's executive officer noted in a 1989 interview that the managerial system designed to promote flexibility and change, the matrix, may itself be nearly impossible to change once it has been in place over a period of years. In that interview, he expressed some dismay with 12 years of the matrix because it seemed to make 
executive relations "more drawn out." When asked if the firm would ever consider restructuring the executive ranks into a traditional hierarchy, he stated that he "wondered if it wouldn't take a merger or a takeover to get rid of the matrix."

5. Theories of economic organizations that assume pure substantive rationality by top managers will poorly predict firm behavior. This last hypothesis is the most speculative and extends the furthest beyond the scope of the data in the present investigation. As many sociologists of organizations have argued, to understand large corporations one must consider how multiple sets of managerial interests and structural factors interact to produce organizational outcomes (Fligstein 1987). Most economic models assume that top managers act according to explicit substantive goals regarding their corporation's operations and future; in effect, the structural contexts in which managers act are undertheorized, and a simple maximization model is assumed to operate in executive decision making (e.g., Williamson 1975).

To be sure, Playco executives do think about substantive organizational productivity, but these concerns are mixed with their framing of their intracorporate conflict as the accumulation of honor through participation in vengeance games. All of this suggests that explanatory frameworks that are based solely on assumptions about top managerial substantive rationality and that exclude systematic attention to the procedural rationality and the symbolic framing of executive interpersonal relations will poorly predict the behavior of the firm.

This study has examined the conflict management at the top of a large corporation. The implications offered above, as well as the observations from which they derive, suggest that cultural and structural approaches to organizational research are neither mutually exclusive nor antithetical. It is not simply a matter of whether structure or culture takes precedence in explaining conflict management and organizational change, but how they intertwine to affect social settings and the people that constitute them. The challenge, then, for scholars is to construct theory that simultaneously recognizes the realities and rationalities of formal and informal structures while not ignoring the impact of symbols in conflict management and organizational life.

\section{APPENDIX A}

Methods

\section{Historical Data}

Historical information on executive conflict management prior to Playco's restructuring, the restructuring itself, and its executives' reac- 
tion to the hostile takeover movement derive from three sources: (1) a systematic review of the popular business press (the Wall Street Journal, Fortune, and Business Week) for reports of Playco's activities from 1965 to 1987 ; (2) a review of Playco internal publications and memoranda from 1965 to 1987; and (3) interviews with Playco personnel (described below) about Playco's history. Data on conflict management prior to the institution of matrix management and the threat of hostile takeovers displayed the most uniform consensus across the three sources used. The overall consensus that developed regarding all of the historical data enhances the confidence in its validity and reliability.

\section{Fieldwork}

I secured access to Playco through a personal tie to a highly respected consultant who had previously worked with the firm. Three months of negotiation followed this initial contact, during which I established an independent identity from the consultant. Fieldwork commenced at Playco's world headquarters in summer 1984 and lasted through fall 1985. Data collection derived from: (1) informal, conversational interviewing (Dalton 1959, p. 280) with every Playco executive $(n=43)$ and many of their support personnel $(n=12)$; (2) formal, semistructured interviews of executives $(n=27)$; (3) direct observation of formal meetings and casual interaction on a regular basis with Playco personnel throughout the 15-month fieldwork period; and (4) the collection of company documents. Interviews averaged 90 minutes in length and observations averaged five hours in length.

During fieldwork, I was seen as a young, bright, naive observer who needed to be educated, as the executives put it, in the ways of the business world. I also found executives extremely lonely in that they had few confidants (except psychiatrists and other counselors they paid) whom they trusted with the delicate insider information of the corporation. Thus I provided a safe haven to talk about the most intimate matters which could be politically disastrous for informants and damaging to the corporation as a whole. Recent details about the firm have been learned from informants who work in various capacities in Playco.

These methods were specifically used to gather information on the contemporary setting of the organization and in the service of a "trouble case" strategy that consists of "search[es] for instances of hitch, dispute, grievance, trouble [between people] and inquiry into what the trouble was and what was done about it" (Llewellyn and Hoebel [1941] 1983, p. 21; see also Nader and Todd 1978, pp. 5-8; cf. Cain and Kulcsar 1982). This strategy yielded information on 39 trouble cases at Playco. 
All trouble cases surfaced in interviews with participants, third parties, uninvolved witnesses, or through direct observation.

Tape recording initially produced self-consciousness in informants. Ethnographic data was thus recorded by jotted notes during conversational interviewing and informal observations, and by extensive note taking during semistructured interviews. These notes became the basis of narratives written on a personal computer as soon as possible after exiting the field.

\section{Data Analysis}

Narratives were initially coded for data on (1) formal and informal organizational structure, firm history, organizational rituals, and personnel biographies and (2) conflict including, principals, third parties, grievance issues, behavior used to handle conflict, timing, and related incidents and cases. The boundaries and language of trouble cases (i.e., their separation from other cases and processes) were supplied by the participants themselves. Categories for conflict management behaviors were also drawn from the anthropology and sociology of conflict, especially the works of Nader and Todd (1978), Black and Baumgartner (1983), Rieder (1984), and Black (1990).

Students of conflict management have used fieldwork and data analysis of this kind to learn of conflict in other cultures (Koch 1974, pp. 13-25; Nader and Todd 1978, pp. 5-8) and in American neighborhoods (Merry 1979; Buckle and Thomas-Buckle 1982; Greenhouse 1986; Baumgartner 1984, 1988). Even so, some investigators note such methods can produce samples containing disproportionately dramatic disputes, thus biasing the data toward more observable processes (Koch 1974, pp. 23-24; Baumgartner 1984, p. 82). This tendency was addressed by triangulating data from written documents and multiple informants. Two "deep" informants (veteran executives) provided detailed member checks and cross-checked the reliability of emic coding categories. 


\section{APPENDIX B}

TABLE B1

\section{Glossary of Playco Conflict Imagery and Hostile Takeover Equivalents}

\begin{tabular}{|c|c|}
\hline Image & Definition \\
\hline Amnesia & Feigned ignorance of a colleague's grievances \\
\hline Ambush & $\begin{array}{l}\text { Covert action to inconvenience an adversary (synonyms: } \\
\text { "bushwhack," and "cheap shot"; "ambush" refers to a } \\
\text { swift and premeditated takeover attempt in takeover im- } \\
\text { agery) }\end{array}$ \\
\hline Art of & Description of the aesthetics of executive comportment \\
\hline Black hat & $\begin{array}{l}\text { An executive who often engages in covert action to manage } \\
\text { conflict with opponents; from the practice of dressing vil- } \\
\text { lains in black hats in early Old West and pirate movies } \\
\text { (synonym: "pirate"; cf. "black knight") }\end{array}$ \\
\hline Black knight & $\begin{array}{l}\text { An executive who often engages in covert action against op- } \\
\text { ponents, does not support his intradepartmental colleagues } \\
\text { in disputes (cf. "black hat"; "black knight" refers to an } \\
\text { unfriendly acquirer from the perspective of an acquired } \\
\text { firm in takeover imagery) }\end{array}$ \\
\hline Blindsiding & $\begin{array}{l}\text { An intentional and surprising public embarrassment by one } \\
\text { executive at another's expense }\end{array}$ \\
\hline Bozo & $\begin{array}{l}\text { An executive who ineptly attempts to follow the code of } \\
\text { honor to press his grievances against opponents (cf. "dick") }\end{array}$ \\
\hline Bullets & $\begin{array}{l}\text { Criticisms of an executive's plan by an opponent delivered } \\
\text { in the midst of a meeting "duel" or "shoot-out" }\end{array}$ \\
\hline Burning fighter & A particularly aggressive executive dispute \\
\hline Bushwhack & $\begin{array}{l}\text { Covert action to inconvenience an adversary (synonyms: } \\
\text { "ambush" and "cheap shot") }\end{array}$ \\
\hline Cavalry & $\begin{array}{l}\text { Departmental executives who come to a colleague's aid in } \\
\text { an interdepartmental dispute }\end{array}$ \\
\hline Call out & Public challenge to a colleague for a "shoot-out" or "duel" \\
\hline Cheap shot & $\begin{array}{l}\text { Covert action to inconvenience an adversary (synonyms: } \\
\text { "ambush" and "bushwhack") }\end{array}$ \\
\hline Crying & $\begin{array}{l}\text { Secretly complaining to a colleague about another's behav- } \\
\text { ior without the offender knowing }\end{array}$ \\
\hline Declaring war & $\begin{array}{l}\text { Collectivization to aggressively and overtly pursue griev- } \\
\text { ances against a collective opponent (also expressed as "to } \\
\text { go to war") }\end{array}$ \\
\hline Dick & $\begin{array}{l}\text { A belligerent executive who ineptly attempts to follow the } \\
\text { code of honor to press his grievances against opponents (lit- } \\
\text { eral reference to the penis; cf. "bozo") }\end{array}$ \\
\hline Dogs on a leash & $\begin{array}{l}\text { Mental health (not having one's "dogs on a leash" indi- } \\
\text { cates mental instability) }\end{array}$ \\
\hline Duel & $\begin{array}{l}\text { Ritualized contest of elaborate formal presentations used to } \\
\text { settle an interdepartmental executive dispute (synonym: } \\
\text { "shoot-out") }\end{array}$ \\
\hline
\end{tabular}


TABLE B1 (Continued)

$\overline{\text { Image }}$ Definition

Executive in distress

Failed gambit

Flak vest

Flight deck

Flying low

Gas attack

Hand grenades

Hiding

Hunting big game

Iron man

Italian lira money order

Jumping ship

Killing an idea

Life vest

Meltdown

Outlaw

Patched up

Peace talks

Pigeon
Executive who ineptly follows the code of honor, but who colleagues feel can be saved; also an honorable executive caught in a "burning fighter" (see also, "white knight"; similar to the notion in takeover imagery of "white knights" rescuing corporations in distress from unfriendly acquiring firms)

Losing an executive "duel" or "shoot-out"

Suit vest worn by honorable executives during a "shootout" or "duel" to ward off "bullets" from the opposition ("flak" refers to impediments to a takeover raised by a target in takeover imagery)

The executive suites in the multistory "main tower" at headquarters from which most "big ideas" are launched Not confronting an offender with long-standing grievances against his or her behavior

Nonverbal expression of scorn for an offending colleague Particularly aggressive insults expressed face-to-face by disputants

Avoiding an opponent

Looking for honorable executives with whom to dispute in order to establish a reputation ("hunting big game" refers to looking for large corporate takeover candidates in takeover imagery)

The senior vice president of operations known for his "stiffness" in interpersonal affairs, his background in the steel industry, and his reputation as one of the most honorable executives at Playco

Reference to the worthlessness of an executive's promise (related to the takeover imagery of "Russian rubles" used to describe early, noncash takeover offers)

Resigning from the corporation

A principal's idea or proposal in a meeting duel is refuted by another principal and then wholly rejected as viable by a wider audience (cf. "withdrawal")

Suit vest worn by less honorable executives when engaged in a "shoot-out" or "duel" to keep their heads above water

Physical fight between executives

An executive who handles conflict in unpredictable ways but who is regarded as especially task competent

An agreement to cease hostilities between disputants Collective negotiations to cease interdepartmental hostilities An executive who avoids all conflict and has a reputation as particularly "weak" (a "pigeon" refers to a highly vulnerable takeover target in takeover imagery) 


\begin{tabular}{cc}
\hline Image & Definition \\
\hline
\end{tabular}

Pirate

Playing the game

Princess of power

Raid

Rape

Red line

Road blocks

Second

Serious player

Shoot-out

Sit down

Skirmish

Sleeping beauties

Small bursts of fire

Strong

Sucked in

Target

Temporary amnesia

Terminator

Texas boys
An executive who often engages in covert action to manage conflict with opponents but who is regarded as especially task competent (synonym: "outlaw"; cf. "black knight" and "black hat")

Engaging in honorable vengeance

The senior vice president of marketing known to have the ear of the chairman of the board, thought to sometimes "succumb" to emotional outbursts, and believed to be the next president of domestic affairs

Covert action taken to inconvenience an opposition department (cf. "ambush," "bushwhack," and "cheap shot"; a "raid" refers to a hostile takeover in takeover imagery)

When an executive allows himself or herself to be publicly criticized by another colleague without "calling out" the challenger

An argument that unpredictably escalates to physical violence (derived jointly from the danger area on gauges for a nuclear reactor and the tachometer on a car)

Impediments raised by an executive to block another's decisions (similar to the hostile takeover imagery of "barricade" meaning impediments to a takeover attempt)

An aide to a principal in a meeting "duel"

An executive who adeptly engages in honorable conflict management (same as a "strong executive" or a "white hat")

Ritualized contest of elaborate formal presentations used to settle an interdepartmental executive dispute (same as "duel")

Negotiations between two principals to suspend a dispute Intradepartmental argument between colleagues

Executives enamored with their own abilities but ignorant of their negative perception by other top managers ("sleeping beauties" refer to vulnerable takeover targets in takeover imagery)

Short public criticisms of a colleague delivered in rapid succession

An executive who adheres to the code of honor in handling trouble with colleagues

To become an ally in an interdepartmental feud through no purposive action of one's own

An opponent in a conflict; typically used by less honorable executives to refer to adversaries

Temporary feigned ignorance of a colleague's grievances

Sales executive who adopted the nickname from Arnold Schwarzenegger's movie of the same name because he closes big deals for Playco and "hunts big game any way he can" Texas takeover men (refers to "big-hat boys" who are Texas moneymen interested in hostile takeovers in takeover imagery) 
TABLE B1 (Continued)

\begin{tabular}{ll}
\hline \hline \multicolumn{1}{c}{ Image } & \multicolumn{1}{c}{ Definition } \\
\hline Waltz around & $\begin{array}{l}\text { Polite argument between less honorable executives (related to } \\
\text { "dancing," which refers to preliminary negotiations during } \\
\text { a takeover in takeover imagery) } \\
\text { Aggressive and overt collective pursuit of grievances against } \\
\text { a collective opponent ("war" refers to an extremely hostile } \\
\text { takeover attempt in takeover imagery; e.g., the American } \\
\text { Express attempt to take over McGraw-Hill in 1979) } \\
\text { An executive who does not adhere to the code of honor in } \\
\text { managing trouble with colleagues } \\
\text { An honorable executive (cf. "black hat," "outlaw," "pi- } \\
\text { rate," "white knight") } \\
\text { An honorable executive who supports his colleagues in inter- } \\
\text { White hat } \\
\text { Whartmental disputes and rescues executives in distress (cf. } \\
\text { "white hat," and "black knight"; "white knight" refers to } \\
\text { an acceptable acquirer sought after by a potential acquiree to } \\
\text { forestall a hostile takeover in takeover imagery) } \\
\text { A successful product team known for its "outlaw" behavior; } \\
\text { named after the Sam Peckinpah movie of the same name } \\
\text { about a notorious band of outlaws in the Old West } \\
\text { Unilateral concession of defeat in a "duel" or "shoot-out" } \\
\text { Senior vice president of R\&D who has numerous inventions } \\
\text { and patents, long hair, and wears loose, hopsack clothing } \\
\text { Eild bunch } \\
\text { Executives who have lost individual conflicts in a larger } \\
\text { "war" with another department ("wounded list" refers to } \\
\text { executives of an acquired firm who develop health or career } \\
\text { problems from the deal in takeover imagery) }\end{array}$ \\
Withdrawal \\
Wizard
\end{tabular}

\section{REFERENCES}

Baumgartner, M. P. 1984. "Social Control in Suburbia." Pp. 79-103 in Toward a General Theory of Social Control. Vol. 2, Selected Problems, edited by Donald Black. Orlando, Fla.: Academic Press.

- 1988. The Moral Order of a Suburb. New York: Oxford University Press.

Berger, Peter L., and Thomas Luckman. 1966. The Social Construction of Reality. New York: Doubleday.

Berger, Peter L., Brigitte Berger, and Hansfried Kellner. 1973. The Homeless Mind: Modernization and Consciousness. New York: Vintage.

Black, Donald. 1984. "Social Control as a Dependent Variable." Pp. 1-36 in Toward a General Theory of Social Control. Vol. 1, Fundamentals, edited by Donald Black. Orlando, Fla.: Academic Press.

- 1990. "The Elementary Forms of Conflict Management." Pp. 43-69 in New Directions in the Study of Justice, Law, and Social Control, prepared by the School of Justice Studies, Arizona State University. New York: Plenum.

Black, Donald, and M. P. Baumgartner. 1983. "Toward a Theory of the Third Party." Pp. 84-114 in Empirical Theories about Courts, edited by Keith O. Boyum and Lynn Mather. New York: Longman.

Bordieu, Pierre. 1965. "The Sentiment of Honour in Kabyle Society." Pp. 191-244 
in Honour and Shame: The Values of Mediterranean Society, edited by J. G. Peristiany. Chicago: University of Chicago Press.

Buckle, Leonard G., and Suzann R. Thomas-Buckle. 1982. "Doing Unto Others: Dispute and Dispute Processing in an Urban American Neighborhood." Pp. 78-90 in Neighborhood Justice: Assessment of an Emerging Idea, edited by Roman Tomasic and Malcolm M. Feeley. New York: Longman.

Butler, Arthur. 1973. "Project Management: A Study in Organizational Conflict." Academy of Management Review 16:84-101.

Cain, Maureen, and Kalman Kulcsar. 1982. "Thinking Disputes: An Essay on the Origins of the Dispute Industry." Law and Society Review 16:375-402.

Carlson, Sune. 1951. Executive Behavior: A Study of the Work Load and the Working Methods of Managing Directors. Stockholm: Strombergs.

Colson, Elizabeth. 1953. "Social Control and Vengeance in a Plateau Tonga Society." Africa 23:199-212.

Dalton, Melville. 1959. Men Who Manage: Fusions of Feeling and Theory in Administration. New York: Wiley.

Davis, Stanley, and Paul R. Lawrence. 1977. Matrix. Reading, Mass.: AddisonWesley.

Eccles, Robert G. 1985. The Transfer Pricing Problem: A Theory for Practice. Lexington, Mass.: Lexington.

Fligstein, Neil. 1987. "The Intraorganizational Power Struggle: Rise of Finance Personnel to Top Leadership in Large Corporations, 1919-1979." American Sociological Review 52:44-58.

Gluckman, Max. (1956) 1967. Custom and Conflict in Africa. New York: Barnes \& Noble.

Greenhouse, Carol J. 1986. Praying for Justice: Faith, Order, and Community in an American Town. Ithaca, N.Y: Cornell University Press.

Hirsch, Paul M. 1986. "From Ambushes to Golden Parachutes: Corporate Takeovers as an Instance of Cultural Framing and Institutional Integration." American Journal of Sociology 91:800-37.

- 1987. Pack Your Own Parachute: How to Survive Mergers, Takeovers, and Other Corporate Disasters. Reading, Mass.: Addison-Wesley.

Hirsch, Paul M., and John A. Y. Andrews. 1983. "Ambushes, Shootouts, and Knights of the Roundtable: The Language of Corporate Takeovers." Pp. 145-55 in Organizational Symbolism, edited by Louis R. Pondy, Peter J. Frost, Gareth Morgan, and Thomas C. Dandridge. Greenwich, Conn.: JAI.

Hoebel, E. Adamson. (1940) 1967. "Law-ways of the Comanche Indians." Pp. 183203 in Law and Warfare: Studies in the Anthropology of Conflict, edited by Paul Bohannan. Austin: University of Texas Press.

Kanter, Rosabeth Moss. 1977. Men and Women of the Corporation. New York: Basic.

Koch, Klaus-Friedrich. 1974. War and Peace in Jalemo: The Management of Conflict in Highland New Guinea. Cambridge, Mass.: Harvard University Press.

Kotter, John. 1983. The General Managers. New York: Free Press.

Llewellyn, Karl, and E. Adamson Hoebel. (1941) 1983. The Cheyenne Way: Conflict and Case Law in Primitive Jurisprudence. Norman: Oklahoma University Press.

Macaulay, Stewart. 1963. "Non-contractual Relations in Business: A Preliminary Study." American Sociological Review 28:55-67.

Martynko, Mark J., and William L. Gardner. 1985. "Beyond Structured Observation: Methodological Issues and New Directions." Academy of Management Review 10:676-95.

Merry, Sally Engle. 1979. "Going to Court: Strategies of Dispute Management in an Urban Neighborhood." Law and Society Review 13:891-926.

Mintzberg, Henry. 1973. The Nature of Managerial Work. New York: Harper \& Row. Moore, Wilbert. 1962. The Conduct of the Corporation. New York: Random House. 
Morrill, Calvin. 1989. "The Management of Managers: Disputing in an Executive Hierarchy." Sociological Forum 4:387-407.

Nader, Laura, and Harry F. Todd. 1978. The Disputing Process: Law in Ten Societies. New York: Columbia University Press.

Peristiany, J. G. 1965. "Introduction." Pp. 9-18 in Honour and Shame: The Values of Mediterranean Society, edited by J. G. Peristiany. Chicago: University of Chicago Press.

Peters, Thomas J., and Robert H. Waterman. 1982. In Search of Excellence: Lessons from America's Best-Run Companies. New York: Warner.

Pitt-Rivers, Julian. 1965. "Honour and Social Status." Pp. 19-77 in Honour and Shame: The Values of Mediterranean Society, edited by J. G. Peristiany. Chicago: University of Chicago Press.

Rieder, Jonathan. 1984. "The Social Organization of Vengeance." Pp. 131-62 in Toward a General Theory of Social Control. Vol. 1, Fundamentals, edited by Donald Black. Orlando, Fla.: Academic Press.

Smelser, Neil J. 1962. The Theory of Collective Behavior. New York: Free Press.

Stinchcombe, Arthur L. 1985. "Authority and the Management of Engineering on Large Projects." Pp. 225-56 in Organizational Theory and Project Management: Administering Uncertainty in Norwegian Offshore Oil, edited by Arthur L. Stinchcombe and Carol A. Heimer. Berge: Norwegian University Press.

Thoden van Velzen, H. U. E., and W. van Wetering. 1960. "Residence, Power Groups and Intra-societal Aggression: An Enquiry into the Conditions Leading to Peacefulness within Non-stratified Societies." International Archives of Ethnography 49:169-200.

Thompson, James D. 1967. Organizations in Action: Social Science Bases of Administrative Theory. New York: McGraw-Hill.

Trice, Harrison M., James Belasco, and Joseph A. Alutto. 1969. "The Role of Ceremonials in Organizational Behavior." Industrial and Labor Relations Review 23:40-51.

Weick, Karl E. 1984. "Small Wins: Redefining the Scale of Social Problems." American Psychologist 39:40-49.

White, Ralph K. 1965. "Images in the Context of International Conflict: Soviet Perceptions of the U.S. and the U.S.S.R." Pp. 236-76 in International Behavior: A Social-Psychological Analysis, edited by Herbert C. Kelman. New York: Holt, Rinehart \& Winston.

Williamson, Oliver. 1975. Markets and Hierarchies: Analysis and Antitrust Implications. New York: Free Press.

Wyatt-Brown, Bertram. 1984. Southern Honor: Ethics and Behavior in the Old South. New York: Oxford University Press. 